ORNL NURE:G-13

P1472

\title{
A Kinetic Model for Predicting the Composition of Chlorinated Water Discharged from Power Plant Cooling Systems
}

$$
\text { M. F. Lietzke }
$$

Preparec for the U.S. NuclearRegulatory Commission

Office of Nuclear Regulatory Fesearcir: Under Interagency Agreement ERDA 40-550-75 
Printed in the United States of Ame:ica Available from National Tecinnical Iniurmation Service

U.S Department o" Commerce

5285 Port Royal Road. Springfieid Jirg'nia 22161

Price Prinied Cop; S4 50. Microhiche 53 00

- 75 recorr was prepared as an account w wurk spor:sored by ine Un:ted Staies

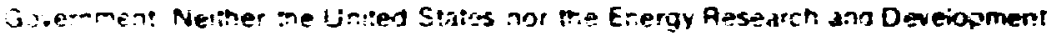
Alm-ristration Uniteg States Nucear Peguiaton, Comm:ss:on. nor any of their

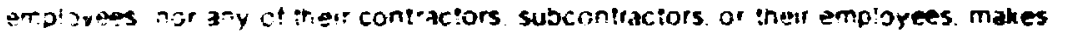

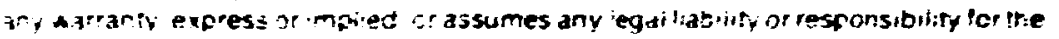
ateirac; completeriess of usetulness of any intormation apparatus product or

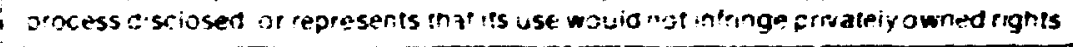


0.0I/muse-13

Diat. Category DC-4

Contract No. W-7405-ens-26

Eocray Division

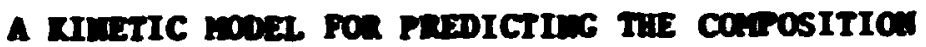

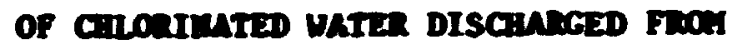

RONER PLAT: COOLIUE STSTIUS

M. H. LIETZXE

Chendetry Division

Mamuscript Completed - February 1, 1977

Date Published - Apri1 1977

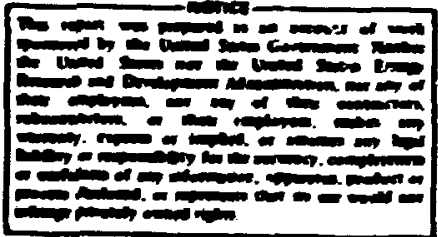

Prepared for the

t.S. Muclear Regulatory Comiseion

Office of muclear Regulatory Research

Onder Iateragency Agrewent DOA $60-550-75$

Prepared by the

ax RIDGe MATIOALL LALONATOXY

Oak R1dge, Tennescee 37830

operated by

unios camide conposation

for the

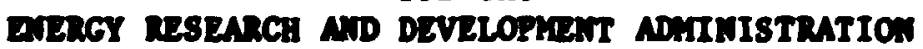

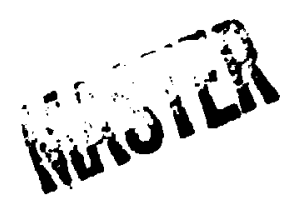

DSTMEUTHON OF. THIS DOCUMENT IS UNUMITED 


\section{CONTENTS}

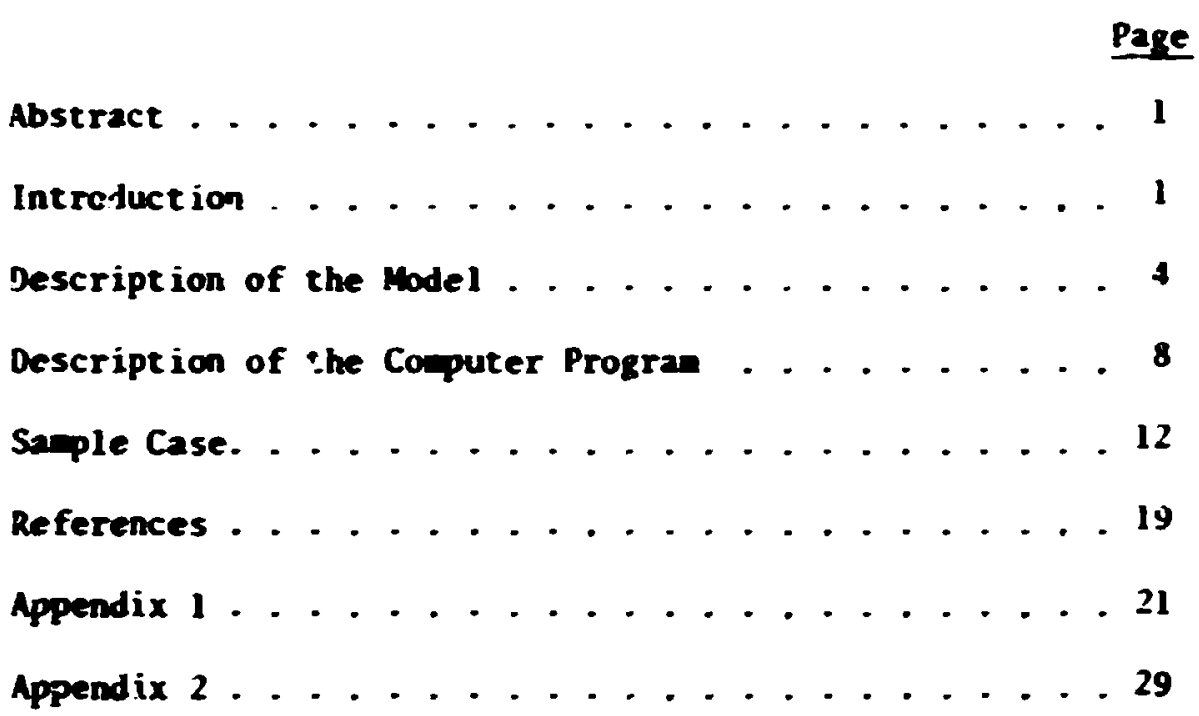


A KIMETIC MODEL FOR PREDICTIHG THE COAPOSITIOA OF CHLORIMTED WATEE DISCHARGED FROH POWER PLANT OXIING SYSTEMS

M. H. Lietzke

\section{ABSTRACT}

A kinetic sodel for predicting the smosition of chlorinated weter dissharged fron power plant cocling systens has been developed. The model incorporates the most importalt chenical reactions that are known to occur when chlorine is added to natural fresh waters. The siaultateous differential equations, which describe the rates of these chenical reactions, are solved nunerically to give the composition of the water as a function of tine. A listing of the acsuter progran is included, along with a Jescription of the input variables. A wor:ied-out example illustrates the application of the progran to an actual cooling systen. An appendix to the report contains a compilation of the known equili!nium and kinetic data for may of the chenical reactions that aight be excountered in chlorinating natural fresi waters.

\section{INTRODUCTION}

Matural wacers used for cooling purposes at power stations way vary Hdely in composition. Depending on the location of the power station, tive cooling water way be efther fresh water, seawater, or water of some intermediate composition. The fresh water usually contains traces of organic anines, other organic compounds (mostly hunic actd), ameonia or ammonium ion, traces of heavy metals, and various anions, as well as bacteria, algae, spores, and viruses. The seawater, on the other hand, contains approximately $3.453 \mathrm{NaCl}$ and an amonium ion concentration that is usually lower than in fresh waters. Other abundant (ag/l or greater) cations in seawater include magnesium, calciun, potassium, and strontium lons, whlle abundant anions include chloride, sulfate, bromide, bicarbonate, borate, sllicate, and fluoride lons. 
In order to pievent sline foration in the cooling syster chlorine is comaly added so the water. The chlorine is rapidly hydrolyzed to yield equinolar quantities of hypochlorous acid and hydrociloric acid. The subsequent cheniscry that occurs in fresh water is fairly well understood. The hypochlorous acid dissoctates into hydrogen and hypochlorite lons, the extent of dissoctation being a function of both ph and temerature. Both the hypochlorcus acid and hypochlorite fon are powerful chlorianting agents. They will react rapioly, for exaple, with amonta or a contur lons co proluce chloranines, vith organtc antaes to produce H-chlorinated anines, and with anino acids to for N-chloroanino acids. Huch of the chlorine is also consuned in satisfying the chlorine demand of the water. The chlorine demand or the water is the difference between the amount of chlorine added and the active (residual) chlorine left. The rates of these various chemical reactions are functions of both the pH and the cemperature of the water. The treated cooling water containing the chloranines and other chlorinated molecules is eventually returned to the biosphere, where the $\mathrm{N}$-chloro compounds slowly hydrolyze.

Most of the thernodynantc and kinetic data needed to model the cheaistry subsequent co the addition of chlorine to natural fresh waters are avallable in the literature. Only the rates of hydrolysis of dichloramine and the organic chloramines have not been directly measured. Howeyer, in lieu of experimental measurements, reasonable estimstes of these quantitles ny be made and used until neasured values becone avallable.

In contrast to the situation wth fresh water, the chendstry of what happens when chlorine 18 added to seavater 18 unknown. The high concentration of chloride may influence the rates of formation and 
destruction of chlorarines. Moreover, the relatively high (ca. 65 ppa) concentration of bromide in seavater ${ }^{2}$ comared to the added shlorine levels will result in the pruduction of hypobronous acid and hypobronite loa. The presence of armiun ion and orgarfc anines will result ta the formation of brumanes as well as chloranines, with the relat?ve concentraticas of each dependent upon pH, temperature, and the amonia to halogen ratio. In addition to the haloanines it is possible that interhalogen complexes my be formed when chlorine is added to seawater. Hence It is apparent that wch experimental work wust be done before a reasonable kinetic nodel can be developed to predict the cheaical species present In efflueat seawater that has been treated with chlorine.

The reason for developing codels to predict the composition of chlorinated cooling water returned to the enviroment fron pover plant cooling systems is to prcuide a means for assessing the environmental impact of such water discharged from existing or proposec power plants. The ajor concern is the coxir. nature of the chloranines and bromanines :La: way persist for hours or even days after blowdown in the waters of a river or estuary. For example, a msive fish-kill in the cooling waters of a large generating station on the shore of Saginaw Bay has been attributed to a lethal concentration of residual shlorine in the vater. Halogen residuals in chlorinated waste-water effluencs have also been responatble for numerous fish kills in the James River estuary." whet her the chloramines or other chlorinated compounds will have a long-terw ef fect on an is at present unknown. In any avent it is now necessary to take cognizance of this problew in assessing the lmpact of power generating stations on the environment. 
RESCRIPTION OF TIF YOUEL.

In developing the sode! used in the present progran for predicting the composition of water discharged from a power plant cooling systen the number of species nas been lept suall. One reason for this is that the model will be incormorated into a la.je unified transpert audel and each species will have to be moved through the environment. The unified transport mode! is the basis for the layge computer progran developed irom consistent matheatical models to simulate the dispersion of heated water and radioisotopic and chemical effluents from power plant discharges. Another resson for keeping the number of species small is that most of the rate constants that would be needed to rafine the model have not been measured as a function of $\mathrm{pH}$ and temperature. These are the rate constants for the forward and backward reactions involving organic nitrogen compounds and hypocnlorous acid. Of those that have been measured, several of the most common have very similar values (at least in the forward direction) and can be odelled as a group using a single rate constant. In the case of our wodel we have chosen methylamine as a stand-in for organic nitrogen. Since the total concentration of dissolved organic material amounts in most natural waters to only a few ppm and may be composed of up to 908 humic materials (constituting the chlorine demand of the water). it would, in any case, be difficult to characterize the particular organic compounds present in a given water. Hence, further refinement of the model does not appear at this time warranted.

The model as formulated takes into account the forward and reverse rates of three chemical reactions leadirg to the formation of chloramines. These are shown as equations (1), (2), and (3). 


$$
\begin{aligned}
& \mathrm{NH}+\mathrm{HOCl} \frac{\mathrm{k}_{1}}{\Gamma-\mathrm{hH}_{2}} \mathrm{CH}_{-1}+\mathrm{H}_{2} \mathrm{O} \\
& \mathrm{WH}_{2} \mathrm{Cl}+\operatorname{m\alpha Cl} \frac{k_{2}}{\sqrt{k_{-2}}} \mathrm{NHCl}_{2}+\mathrm{H}_{2} \mathrm{O} \\
& \mathrm{RXH}_{2}+\operatorname{HOCl} \frac{\mathrm{k}_{j}}{\sqrt{k_{-3}}} \mathrm{RHFC}+\mathrm{H}_{2} \mathrm{O}
\end{aligned}
$$

The specie.s $\mathrm{RVH}_{2}$ in equation (3: represents a compesice of the organic anines present in the water. As previcusly mentioned, the value of $k_{3}$ used in the program is that for the reaction of athylamine with hypochlornus acid. Of the rearining rate constatts $k_{1}, k_{-1}$, and $k_{2}$ are known. In lieu of easured values of $k_{-2}$ and $k_{-3}, k_{-3}$ has been taken equal to $k_{-1}$, while $k_{-2}$ has been assumed to be equal to $1 / 2 k_{-1}$. These six rate constants are the theoretical rate constants for the chemical reactions as writien. In practical calculations, however, it is inconvenient to use the theoretica! rate const ints in the differential equations since the hypochlorous acid will be partially dissuciated and the ammia and organic amines will be in equilibrium with their amonium ions. Ise of the corresponding observed rate constants for the reactions takes into account these equilibria, which are functions of both phi and temperature. The theoretical rate constart; are the refore converted in the prozram into the corresponding observed rate constants for the conditions of $\mathrm{pH}$ and temperature specified. Fxprcssions for the conversions are given in Appendix 2. Temperature dependent expressions for the theoretical rate corstants are shown in Table 1. Temperatures are in degrees Centigrade. 
TABLE I

TEMPERATURE DEPEXDENT EXPRESSIONS FOR THE THEORETICAL RATE CONSTAITS OF EQUATIONS 1, 2, AND 3

$$
\begin{aligned}
& k_{1}=3.86286 \times 10^{6}+3.09048 \times 10^{4} t+5.52381 \times 10^{2} t^{2} \\
& k_{2}=1.17429 \times 10^{2}+3.57857 t+0.212957 t^{2} \\
& k_{3}=2.33667 \times 10^{8}+3.26006 \times 10^{6} t \\
& 1 n k_{-1}=-13.036+0.113091 t-3.27212 \times 10^{-4} t^{2} \\
& k_{-3}=k_{-1} \\
& k_{-2}=0.5 k_{-1}
\end{aligned}
$$

The rates of the forward reactions resulting in the formation of the chloramines are extremely rapid, while the reverse reactions for the hydrolysis of the shloranines are much slower. For example, in the pH range $7-8$ at a temperature of $25^{\circ}$ the forward reactions consure the hypochlorous acid in a few minutes, while half-times for the hydrolysis of the chloramines (resulting in the regeneration of the original amines) are weasured in hours. The small amount of hypochlorous acid formed by hydrolysis of the chloramines in the cooling system is disregarded after the initial consumption of the added chlorine.

In addition to the three chemical reactions leading to the formation of chloramines, the model includes an equation for the rate of irreversible uptake of chlorine in satisfying the chlorine demand of the water. The va!ue of the rate constant for this reaction must be adjusted by trial and error so that under the conditions prevailing in a natural water of 
given composition about $90^{\circ}$ of the chlorine added goes into satisfying the chlorite demand of the water. Fast-acting and slow-acting chlorine demand have been combined into this one equation.

In a once-through cooling system the makeup to blowdown ratio is unity and hence chlorine is added to water contziring the same conceritrations of dissolved substances as the makeup water. In a recirculating syster with cooling towers, on the other hand, the chlorine is added to water in which the dissolved substances have become concentrated by a factor aqual to the makeup to blowdown ratio. The computer program has been designed to handle either type of configuration. Losses of chlorine by evaporation and by reaction with material attached to the walls of the cooling syster are small and have been disregarded.

A final assumption made in this model is that the chlorine added to the water is immediately dispersed throughout the cooling systen, rather than heing added over a short period of time. Since the time between successive additions of chlorine may be of the order of eight hours this assumption should not have a very large effect on the calculated values of the total residual chlorine discharged from the sysrem after chlorination has ceased.

In developing the foregoing model a survey of the literaturc was made to compile available information on the lecessary equilibrium and rate constants. Unfortunately these data are scattered in the literatur ${ }^{5}$ and in many cases difficult to find. Available data on the most important equilibria and reactions involved ir chloramine forinsition have therefore been summarized in Appendix 2 of this rep.urt. In each case reference is made to the source of the data. 
DESCRIPTION OF THE COMPUTER PROGRAM

The differential cquations representing the chemical system are shown as equations (4), (5), (6), and (7).

$$
\begin{aligned}
& \frac{d\left[\mathrm{NH}_{2} \mathrm{Cl}\right]}{d t}=k_{1}\left[\mathrm{NH}_{3}\right][\mathrm{HOCl}]-k_{-1}\left[\mathrm{NH}_{2} \mathrm{Cl}\right]-k_{2}\left[\mathrm{NH}_{2} \mathrm{Cl}\right][\mathrm{HOCl}]+ \\
& k_{-2}\left[\mathrm{NHCl}_{2}\right]-F_{\mathrm{BD}}\left[\mathrm{NH}_{2} \mathrm{Cl} ;\right. \\
& \frac{d\left[\mathrm{NHCl}_{2}\right]}{d t}=k_{2}\left[\mathrm{NH}_{2} \mathrm{Cl}\right][\mathrm{HOC} 1]-k_{-2}\left[\mathrm{NHCl}_{2}\right]-\mathrm{F}_{\mathrm{BD}}\left[\mathrm{NHCI_{2 }}\right] \\
& \frac{d[R N H C]]}{d t}=k_{3}\left[R_{2}\right][H O C 1]-k_{-3}[R N H C 1]-F_{B D}[R N H C 1] \\
& \frac{d\left(x_{4}\right]}{d t}=k_{4}\left[C 2-x_{4}\right][40 C 1]-F_{B D}\left[x_{4}\right]
\end{aligned}
$$

In equation (7) the quantity CD refers to the chlorine demand of the water. $x_{4}$ refers to the amount of chlorine consumel in satisfying the chlorine demand, and $k_{4}$ is the rate constant for this reaction. The rate constant $F_{B D}$ appearing in all the equations represents the fraction of the total volume of chlorinated water discharged per unit time. It is calculated by dividing the blowdown rate by the total volune of the chlorinated water.

In addition to these four differantial equations a fifth differential equation is included to cnlculate the concentration of HOCl remaining afte. each tine step. 


$$
\begin{aligned}
\frac{d[H O C]}{d t} & =-k_{1}\left[\mathrm{NH}_{3}\right][\mathrm{HOCl}]+k_{-1}\left[\mathrm{NH}_{2} \mathrm{Cl}\right]-k_{2}\left[\mathrm{NH}_{2} \mathrm{Cl}\right][\mathrm{HOCl}] \\
& +k_{-2}\left[\mathrm{NHCl}_{2}\right]-k_{3}\left[\mathrm{RNH}_{2}\right][\mathrm{HOCl}]+k_{-3}[\mathrm{RNHCl}] \\
& -k_{4}\left[\mathrm{CD}-\mathrm{X}_{4}\right][\mathrm{HOCl}]-\mathrm{F}_{\mathrm{BD}}[\mathrm{HOCl}]
\end{aligned}
$$

These five differential equations are solved simultaneously using a variable step-size Runge-Kutta integration scheme to give the concentrations of $\mathrm{NH}_{2} \mathrm{Cl}, \mathrm{NHCl}_{2}$, $\mathrm{RNHCl}$, and $\mathrm{HOCl}$ remaining in the cooling system after each time step. The concentrations of $\mathrm{NH}_{3}$ and $\mathrm{RNH}_{2}$ in the cooling system are calculated after each time step by subtracting the corcentrations of $\mathrm{NH}_{2} \mathrm{Cl}$ and $\mathrm{HHCl}_{2}$ from the original concentration of $\mathrm{NH}_{3}$ and the concentration of RNHCl from the original concentration of $\mathrm{RNH}_{2}$. The concentrations of $\mathrm{NH}_{3}$ and $\mathrm{RNH}_{2}$ will at first decrease following chlorination, then build up agajn as fresh make-up water is brought into the cooling system.

Provision 15 also made in the computer progran for a diluticn factor in case the blowdown is diluted before discharge, If no further dilution occurs this factor is unity. 
DEFINITIONS OF THE VARIABLES WHICH

COMPRISE THE INPUT TO THE PROGKAM

$\operatorname{TMP}$

PH

CL

NH3

RNH2

CDO

as

RF1

vCS

DLF

To

TI

Ii

TSTEP

ITS

IFLAG

RK4
Temperature of the water in the cool ing system in " $C$.

$\mathrm{pH}$ cf the water

Arount of chlorine added to the cooling water (Ppa). It is assumed that the chloiine is well mixed and instantaneously dispersed throughout the cooling water syster.

Acount of inorgaric nitrogen as $\mathbf{N H}_{3}$ in the makeup water (ppia).

Amount of organic anines in the makeup water (ppa)

- modelled by $\mathrm{CH}_{3} \mathrm{NH}_{2}$ in the program,

Total chlorine demand of the makeup water (ppm).

Rate at which akeup water is addel to the cooling systen (gallons per second).

Blowdown rate (gallons per second) RF/RFl, the wakeup to blowdown ratio, is referred to as $\mathrm{Mi} / \mathrm{BD}$ in the output.

Total volume of the cooling system to which chlorine is added (gallons).

Dilution factor after blowdown. If no dilution, DLF $=$ 1.0

Time at start of chlorination (TO $=0$ ).

Uuration of time in minutes between successive additions of chlorine.

If $I T=M$ outpat $w i l l$ be in einutes. If IT $=5$ output will be in seconds.

Timestep to be taken it the start of the integration. This must be short. A suggested value is .001 minutes."

If ITS $=M$ timestep $w$ ill be in minutes. If ITS $=S$

timestep will be in seconds.

Integer specifying whether output is to be in molarity or in ppm. If IFLAG $=0$ output is in molarity. If IFLAG $\approx 1$ output is in ppm.

Rate constant for equation (7). 
The foregoing variables are input to the progran on three cards accorring to the format shown in Table 2.

- Since terms drop out of the differential equations as soon as the $H O C I$ is consumed, it is necessary to take a very small time step at the start of the integration to ensure that the initial slopes are well detersined.

TABLE II

INPUT DATA

\begin{tabular}{|c|c|c|c|}
\hline Card No. & Field & Variabie & Forwat \\
\hline \multirow[t]{8}{*}{1} & $1-10$ & $\operatorname{TMP}$ & F10.0 \\
\hline & $11-20$ & PH & $F: 0.0$ \\
\hline & $21-30$ & $\mathrm{CL}$ & $F 10.0$ \\
\hline & $31-40$ & NH3 & Fi.s. 0 \\
\hline & $41-50$ & RNH2 & F10.0 \\
\hline & $51-60$ & $\mathrm{CDO}$ & $F 10.0$ \\
\hline & $61-70$ & $\mathbf{R F}$ & $F 10.0$ \\
\hline & $71-80$ & PFI & $F 10.0$ \\
\hline \multirow[t]{9}{*}{2} & $1 \cdot 10$ & vcs & E10.0 \\
\hline & $11-2 c$ & DLF & $\therefore 10.0$ \\
\hline & $21-30$ & TO & E10.0 \\
\hline & $31-39$ & $\mathrm{T1}$ & F 9.0 \\
\hline & 40 & $1 T$ & $\mathbf{A l}$ \\
\hline & $61-49$ & TSTEP & F 9.0 \\
\hline & so & ITS & Al \\
\hline & $51-55$ & IFLAG & 15 \\
\hline & $56-60$ & NCLC & IS \\
\hline 3 & $1-10$ & RKA & $E 10.0$ \\
\hline
\end{tabular}




\section{SAMPLE CASE}

Three MIle Island Nuclear Station located near Harrisburg, Pennsylvania, uses both a recirculating and a once-through river water cooling system. Data have been taken from a report ${ }^{6}$ on cooling water chlorination practices at this station in order to test the model and computer progran presented in this report. The calculations apply to Unit 1 of the recirculating system, for wich the most reliable data are available, and to the once-through river water system.

Craracteristics of the makerup water, as given in Table 9 of the report, are as follows: pH 7.2; total chlorine demand 2.6 ppm; nitrogen as $\mathrm{NH}_{3} 0.17 \mathrm{ppm}$; terperature $25.5^{\circ} \mathrm{C}$. No mention is made of organic amines in the water.

Characteristic values for the once through system are: 29,000 GPM river water straight through; approximate volune of the once through system $1.0 \times 10^{6} \mathrm{C}$. If it is assumed that the water is chlorinated $0.35 \mathrm{ppm}$ above the imsediate chlorine demand, this amounts to about 0.85 ppm chlorine in the river water systom inmediately after chlorination (with the assumption that the chlorine is instantaneourly dispersed and well mixed).

Characteristic values for Unit 1 of the recirculating system are: make-up water 11,250 GPM; blowdown 2,000 GPM; volume of the recirculating system $1.3 \times 10^{7} \mathrm{G}$. The blowdown makes up 73 of the total discharge. If it is assumed that the chlorine is instantaneously dispersed and well mixed in the recirculating system, then $6000 \mathrm{lbs}$ of chlorine per day (assume 2000 lbs three times a day) in the total recirculating system would amount to $9.2 \mathrm{ppw}$ chlorine in the water of Unit 1 immediately after chlorination. 
Using the above numbers the input paraneters for the conputer progran are:

A. For the River Water Systen

\begin{tabular}{|c|c|c|}
\hline TIP & 25.5 & (deg. C) \\
\hline PH & 7.2 & (ppm) \\
\hline Cl & 0.845 & (ppm) \\
\hline NH3 & 0.17 & (ppin) \\
\hline RNH2 & 0 & (Ppm) \\
\hline CDO & 2.64 & (ppm) \\
\hline RF & 483.33 & $\left(29,000 / 60 \sec ^{-1}\right)$ \\
\hline RF1 & 483.33 & $\left(29,000 / 60 \sec ^{-1}\right)$ \\
\hline vcs & $1.0 \times$ & $10^{6}$ (gallons) \\
\hline DLF & 1.0 & \\
\hline TO & 0 & \\
\hline$T 1$ & 480 & (480 min. or $8 \mathrm{hrs}$ ) \\
\hline IT & $M$ & \\
\hline TSTEP & .001 & (min.) \\
\hline ITS & $\mathbf{M}$ & \\
\hline IFLAG & $1 \quad(s 0$ & $\begin{array}{l}\text { that output will } \\
\text { be in ppin) }\end{array}$ \\
\hline NCLC & 8 (e) & $\begin{array}{l}\text { ight chlorination } \\
\text { cycles) }\end{array}$ \\
\hline RK4 & $1,0 \times 1$ & $\begin{array}{c}0^{4}(\text { liters } \\
\text { sec. }\end{array}$ \\
\hline
\end{tabular}


B. For the Recirculating Systen

\begin{tabular}{|c|c|c|}
\hline $\mathbf{T P}$ & 43. & $(\operatorname{deg} \cdot c)$ \\
\hline PH & 7.2 & (ppa) \\
\hline CL & 9.2 & (ppa) \\
\hline LH3 & 0.17 & (ppm) \\
\hline RNH2 & 0 & (ppm) \\
\hline $\mathrm{CDO}$ & 2,64 & (ppm) \\
\hline RF & 187.5 & $\left(\sec ^{-i}\right)$ \\
\hline RFI & 33.333 & $\left(\sec ^{-1}\right)$ \\
\hline VCS & $1.3 \times$ & $10^{7}$ (gallons) \\
\hline DLF & 14.3 & \\
\hline TO & 0. & \\
\hline TI & 480 & (min.) \\
\hline IT & $M$ & \\
\hline TSTEP & .001 & $(\min )$. \\
\hline ITS & M & \\
\hline IFLAG & 1 & \\
\hline MCLC & 8 & \\
\hline RK4 & 500. ( & $\begin{array}{l}\text { iters wole } e^{-1} \\
\left.\sec ^{-1}\right)\end{array}$ \\
\hline
\end{tabular}


When the compter progran was run for eight successive chlorination cycles the following results were obtained:

In the case of the river water systen the $\mathrm{HOCl}$ produced by hydrolysis of the added chlorine is almost imediately consumed by the chlorine dewand in the water and by reaction with the amonia to form $\mathrm{NH}_{2} \mathrm{Cl}$. With the assuption that the chlorine is instantaneously dispersed throughout the system the maxime amount of $\mathrm{MH}_{2} \mathrm{Cl}$ formed is $.016 \mathrm{ppm}$. This would lead to ca. .01 ppa total residual chlorine in the discharge firr vbeut: five minutes. In actual practice, since it takes 15 to 20 minutes for the chlorinated water to reach the discharge point, the effluent water probably never contains as much as $.01 \mathrm{ppa}$ total residual chlorine because of chlorination of the river water system. The anount of $\mathrm{NHCl}_{2}$ formed is insignificant (max. $3.9 \times 10^{-13} \mathrm{~m}$ ).

In the recirculating system the makeup to blowdown ratio is fairly high (5.63). Both the chlorine demand and the $\mathrm{NH}_{3}$ becone concentrated in the water by this factor. The anount of chlorine added (9.2 $\mathrm{ppm}$ ) is relatively high while the concentration of $\mathrm{NH}_{3}$ in the water is rather low. As can be seen in Fig. 1, when chlorine is added to the water the first time the $\mathrm{NH}_{3}$ is almost imediately consuned, resulting in the formation of both $\mathrm{NH}_{2} \mathrm{Cl}$ and $\mathrm{NHCl}_{2}$. The remaining $\mathrm{HOCl}$ is taken up by the chlorine demand in the water. The anount of $\mathrm{NH}_{2} \mathrm{Cl}$ formed is predicted to reach $3.51 \mathrm{ppm}$, while the $\mathrm{NHCl}_{2}$ reaches .08 $\mathrm{ppm}$. After a Iittle more than two hours hydrolysis and blowdown reduce the $\mathrm{NH}_{2} \mathrm{Cl}$ concert ration to below one Ppm; this value falls to .04 ppa ifter 8 hours, while the $\mathrm{NHCl}_{2}$ concentration falls to less than $.01 \mathrm{ppm}$. The pattern is repeated during subsequent chlorination cycles, with the system coming 


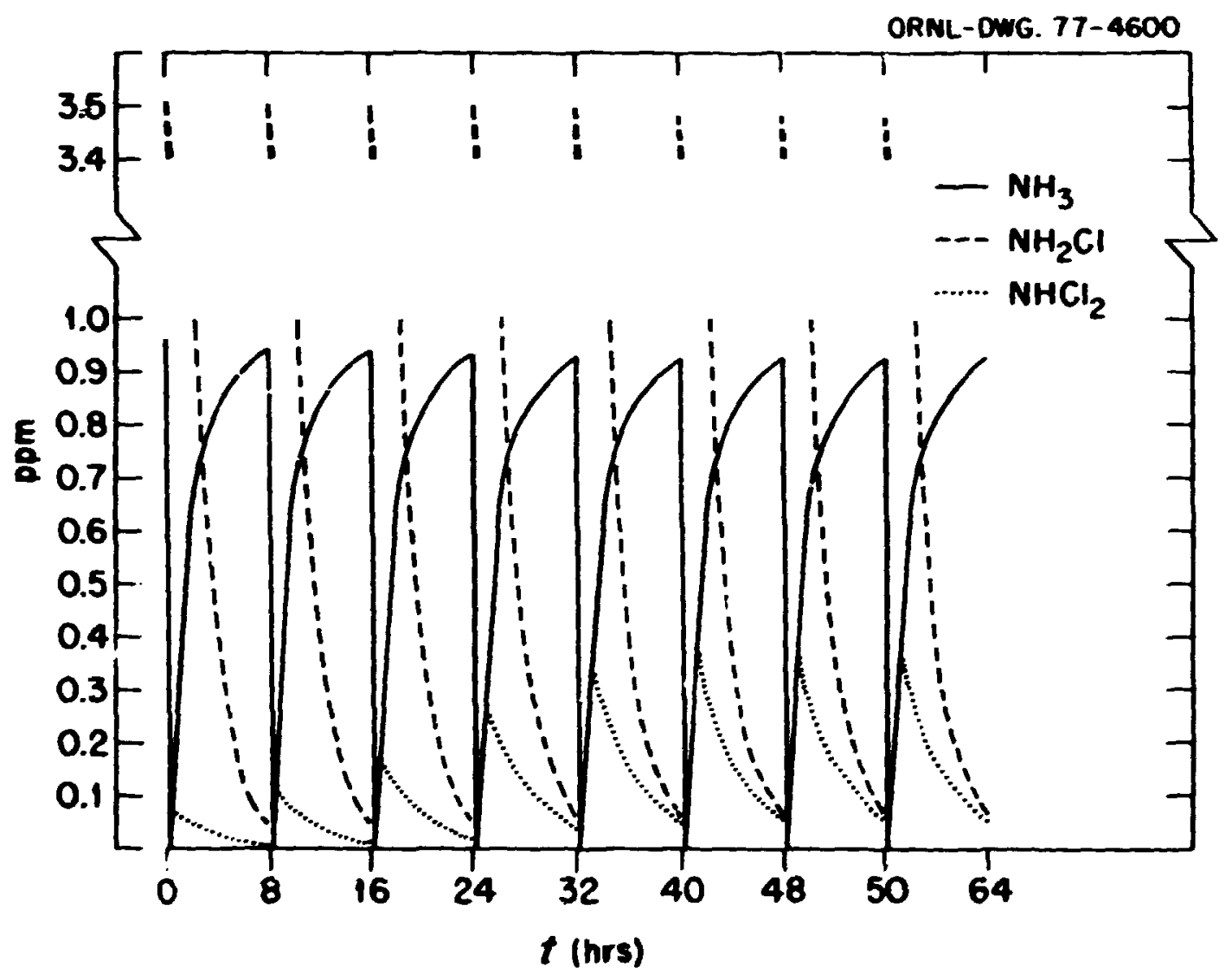

Fig. 1. The Amounts of $\mathrm{NH}_{2} \mathrm{Cl}, \mathrm{NHCl}_{2}$, and $\mathrm{NH}_{3}$ in the Recirculating System During Eight Chlorination Cycles 
to equilibriu after five cycles. In the sixth and succeeding cycles the maxim predicted anount of $\mathrm{NH}_{2} \mathrm{Cl}$ in the systen is $3.48 \mathrm{ppm}$ inmediately after chlorination and .C66 ppa at the end of the cycle, while the corresponding asounts of $\mathrm{Mxi}_{2}$ are $.48 \mathrm{ppa}$ and .05 ppa.

The anounts of total residual chlorine in the discharge fron the recirculating systen (after dilution) are shown for seven chlorination cycles in Table 3. Again equilibriu is reached after five cycles. These values probably represent upper limits because of potential losses of chlorine neglected in the codel: e.g., losses due to evaporation, cooling tower drift, and other cheaical reactions involving chlorine.

The values of the rate constants (RK4) used in both cases for the consumption of chlorine by the chlorine denand of the water were found by trial. Increasing the value above $5 \times 10^{5}$ did not result in a significant increase in the consuption of chlorine by the chlorine deand in the river water system and hence this value was used. The chlorine demand wis only about 30 satisfied in this system. In the recirculating water system a value of 500 for RK4 resulted in the total chlorine demand of the water being about $90 t$ satisfied.

The total time required to compile the progran and run both cases was $\$ .3$ seconds on the 1 M $360 / 91$ computer. 
TABLE III

TOTAL RESIDUAL CHLORISE IN DISCHARGE (ppa)

Chlorination Cycle

\begin{tabular}{cccccccc}
\hline Tine & 1 & 2 & 3 & 4 & 5 & 6 & 7 \\
\hline 1 nin. & 0.172 & 0.173 & 0.192 & 0.225 & 0.263 & 0.276 & 0.277 \\
10 nir. & 0.158 & 0.162 & 0.168 & 0.176 & 0.179 & 0.180 & 0.180 \\
1 hr. & 0.100 & 0.103 & 0.107 & 0.114 & 0.118 & 0.119 & 0.119 \\
2 hr. & 0.059 & 0.063 & 0.064 & 0.069 & 0.072 & 0.074 & 0.074 \\
3 hr. & 0.034 & 0.035 & 0.037 & 0.042 & 0.045 & 0.046 & 0.046 \\
$4 \mathrm{hr}$. & 0.0199 & 0.021 & 0.023 & 0.026 & 0.029 & 0.030 & 0.030 \\
$5 \mathrm{hr}$. & 0.012 & 0.013 & 0.014 & 0.016 & 0.019 & 0.019 & 0.019 \\
$6 \mathrm{hr}$. & $<.01$ & $<.01$ & $<.01$ & $<.01$ & 0.012 & 0.013 & 0.013 \\
$7 \mathrm{hr}$. & $<.01$ & $<.01$ & $<.01$ & $<.01$ & $<.01$ & $<.01$ & $<.01$ \\
$8 \mathrm{hr}$. & $<.01$ & $<.01$ & $<.01$ & $<.01$ & $<.01$ & $<.01$ & $<.01$ \\
\hline
\end{tabular}

The author wishes to express his sincere appreciation to Drs. R. W. Stoughton, H. E. Zittel, M. R. Patterson, D. E. Arnurius, and R. L. Jolley for helpful discussions and suggestions concerning this program. 


\section{REFERENCES}

1. This report is one of a ser es that will be issued under the Unified Transport Progran. A. H. E: aslan et al, "Unified Transport Approach for the Assesswent of Power Plant Impacts," Energy Division Annual Progress Report, ORNL-5124, April 1976.

2. K. S. Spiegler, "Salt Water Purification," Wiley, New York, 1962.

3. B. Ingersoll, "Tie Chlorine Discharges, Fish Die-off," Chicago Sun-Times, January 9:5 (19i2).

4. M. A. Rellanca and D. S. Bailey, "A Case History of Some Effects of Chlorinated Effluents on the Aquatic Ecosystem of the Lower Janes River in Virginiz. Abstract, 48th Annual Conference, water Pollution Control Fejeration, Washington, D.C., 1975.

5. R. L. Jolley, "Chlorination Effects on Organic Constituents in Effluents from Domestic Sanitary Sewage Treatment Plants," PhD Dissertation, University of Tennessee, 1973.

6. "Development of Cooling Water Chlorination Practices at the Three Mile Nuclear Station, Final Report, February 27, 1976," Wapora, Inc., Washington, D.C. 
Appendix 1

Listing of the FORTRAN Program 


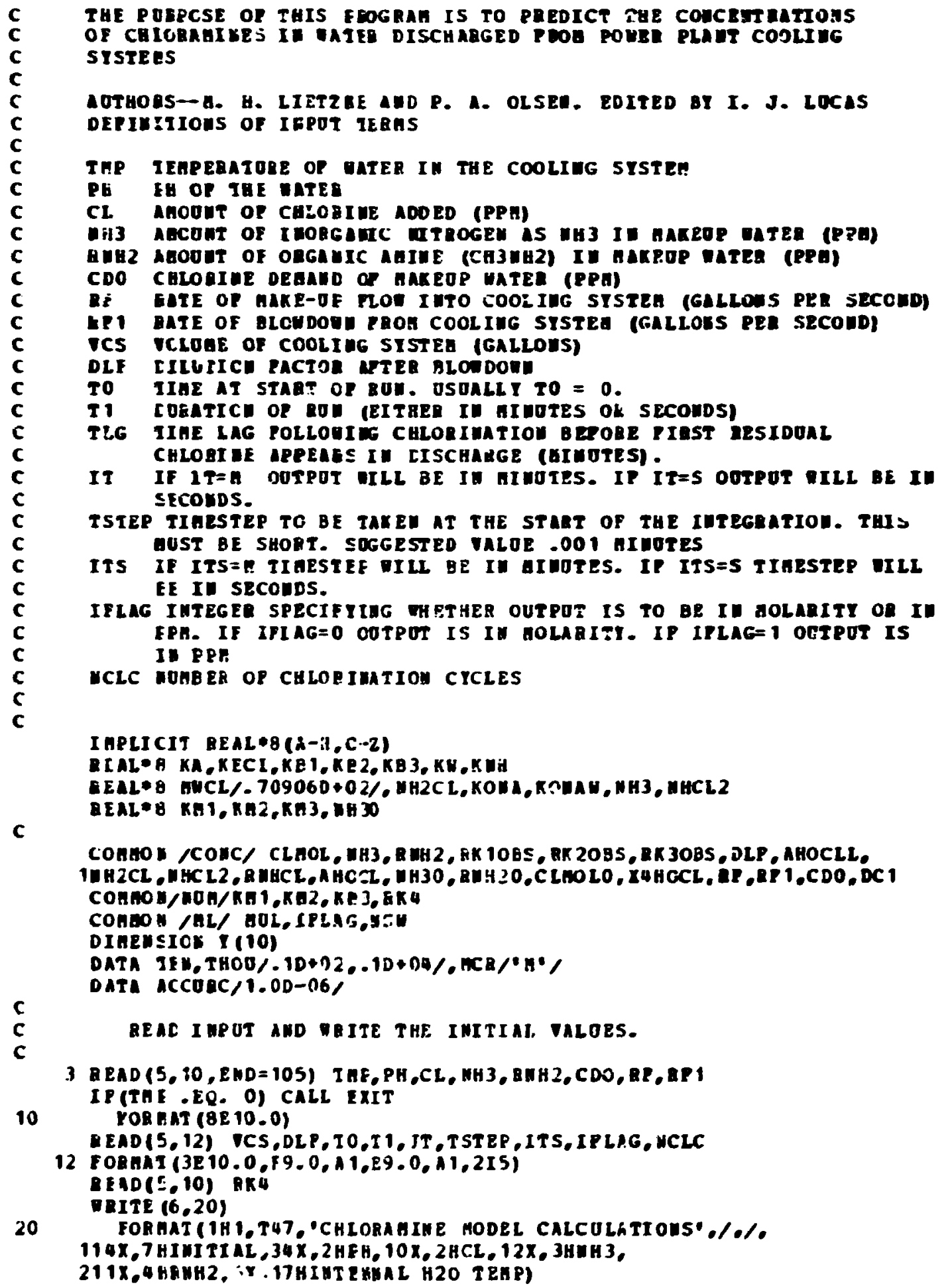




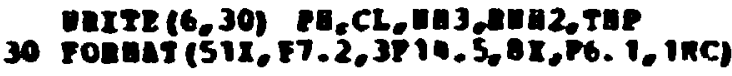

c

C

C

C

C

c

c

c

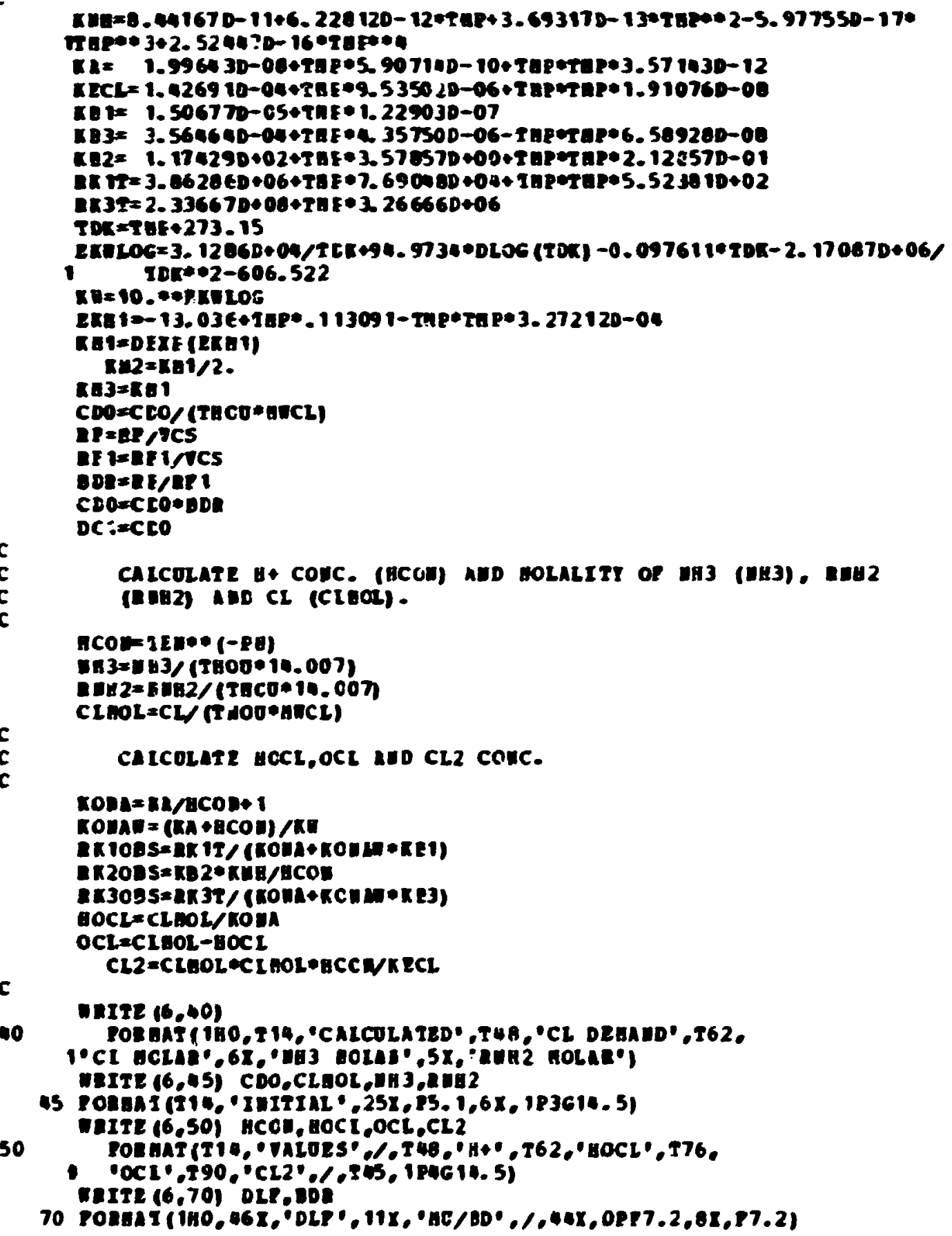

10 
110

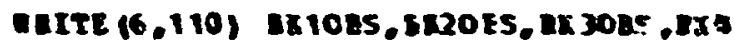

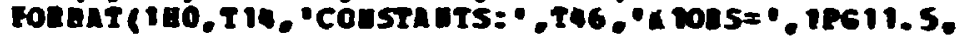

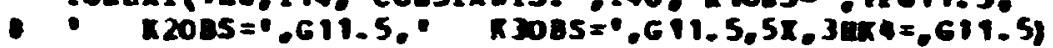

C

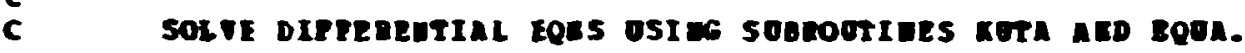

C

60

WEITE 16,60$)$ T0,LT,T1,IT,TSTEP,ITS

rouant (180,, 121, "To=:

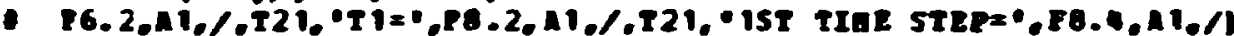
Q⿻112 (16.95)

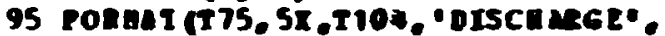

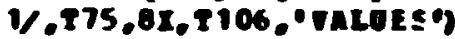

enIz 16,100$)$

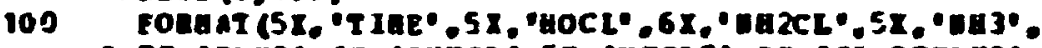

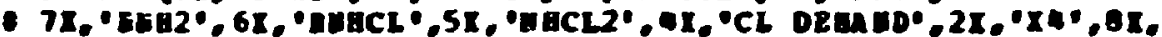

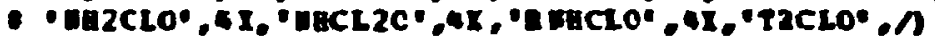

$D L F=1.000 / 0 L F$

MB 3× 1539800

e

II $30=743$

$\operatorname{cog} 20=8$ wa 2

ABOCLI $=0$.

DO $101 \mathrm{I}=1,8$

$101 \mathrm{I}(\mathrm{I})=0$.

DIZCL $=1$ (1)

DACL $2=9$ (2)

IUECL $=1$ (3)

aOL $=1$

IF(IT.DE. ECA) 603062

$70=70 * 60$.

$T I=T 1 * 60$.

62 IP(ITS.EQ.HCR) $90 L=60$

TSTEP = TST EP $\bullet$ nDL

DO 2 CO $R=1$, ICLC

$\|=5$

TO= TO

$T I=T I$

DEL $=$ T STRP

I $\operatorname{CAX}=700$

CLEOLO=CLEOL

CALL ROTA (T0, 11,1,1,0E, ACCOAC, IAAX)

CLBOL $=C W$ (T BOR・GICL)

$199 \mathrm{~T} I=T 1 / 60$.

200 CCUTINOE

GO 103

105 COITI UOE

STOP

END 
c

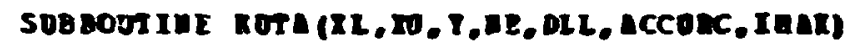

C

IAPLICIT AEALOA $(a-\pi, 0-z)$

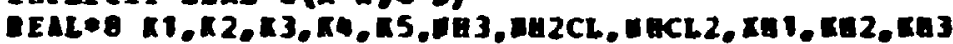

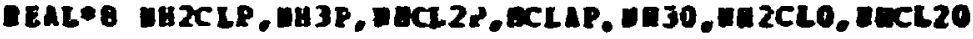

C

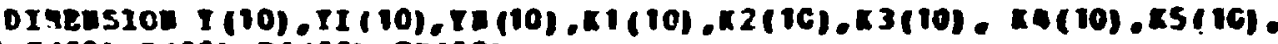
IFi(10),E(10),PI(10) . IA (10)

c

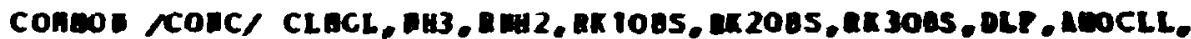

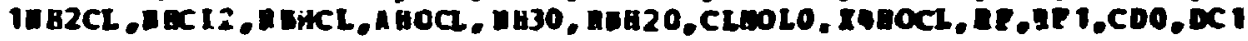

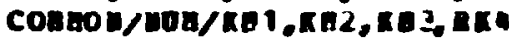
COaso: /GL woL, IPLAG,SSE

c LOGICAL QEIT, TIRST

AIMC $=$ I SORT (OSCET (2. CO))

15\%=0

ITIEE $=0$

$\boldsymbol{m}=\mathbf{m e}$

$x=\mathbf{I I}$

AHCL $=$ CLEOLO+ $A H O C L$ L

$I(0)=A B O C L$

IAEOC! $=1(5)$

TACLO $=.689 * I(6)+.826 * I(7)+.541 * 1(8)+.676 * A 40 C L L * D L P$

IF (IFIAG - EG. II 60 IC 600

MRITE (6,7 1) XW,AHOCR, WH2CL, WH3, BWH2, MHGCL, WHCL2,CDO, XAHOCL,

$11(6), 1(7), 12(8)$, TaCLO

71 Ponat (1x, F8, 3,3x, IF 12E1U.2)

GO TO 601

600 AHCLLF $=A 40 C L L=5.266 \mathrm{C}+4$

CLEOLF $=$ CLEOL $7.0906 \mathrm{D} * 4$

AHOCLF $=$ AHOCLES. $2460+4$

$C D O P=C D 0=7.0906 D+4$

$\triangle H 3 P=$ BH 3*?. $9007 \mathrm{D}+4$

$\operatorname{MB2P}=9 \mathrm{EH} 2 * 1.9007 \mathrm{D}+4$

$B H 2 C L E=I(1)=5.1476044$

MUCL2E = I (2) $\bullet 8.59210 * 4$

QBACLF $=1(3) \bullet 6.55030 * 4$

$X+H C L F=X 4 H O C L=7.09060 * 4$

ACLAP $=1(6)+5.14760+4$

DCLAP = I (D) $\bullet 9.5920+4$

$O C L A P=I(8)=6.55030 * A$

TACLPC $=.669 *$ ACLAP $+.541 * 0 C L A P * .825 * D C L A P * .676 * A H C L L P * D L P$

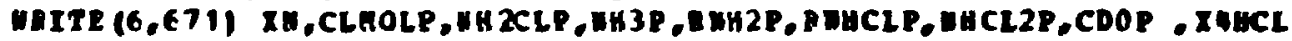

1P.ACLAE,DCLAP,CCLAR, TECLPO

671 Posent $(1 x, 78,3,2 x, P 8,3,17510.4)$

$601 \mathrm{H}=\mathrm{DLL}$

PIn $5 T=2808$.

QOTT=. PLSE.

DO $10 I=1$,

$10 \quad I I(I)=1(I)$

20 IP(H. .GI. 360.) $H=360$.

IP $(X N+H . L T-I 0)$ Go IC 30 


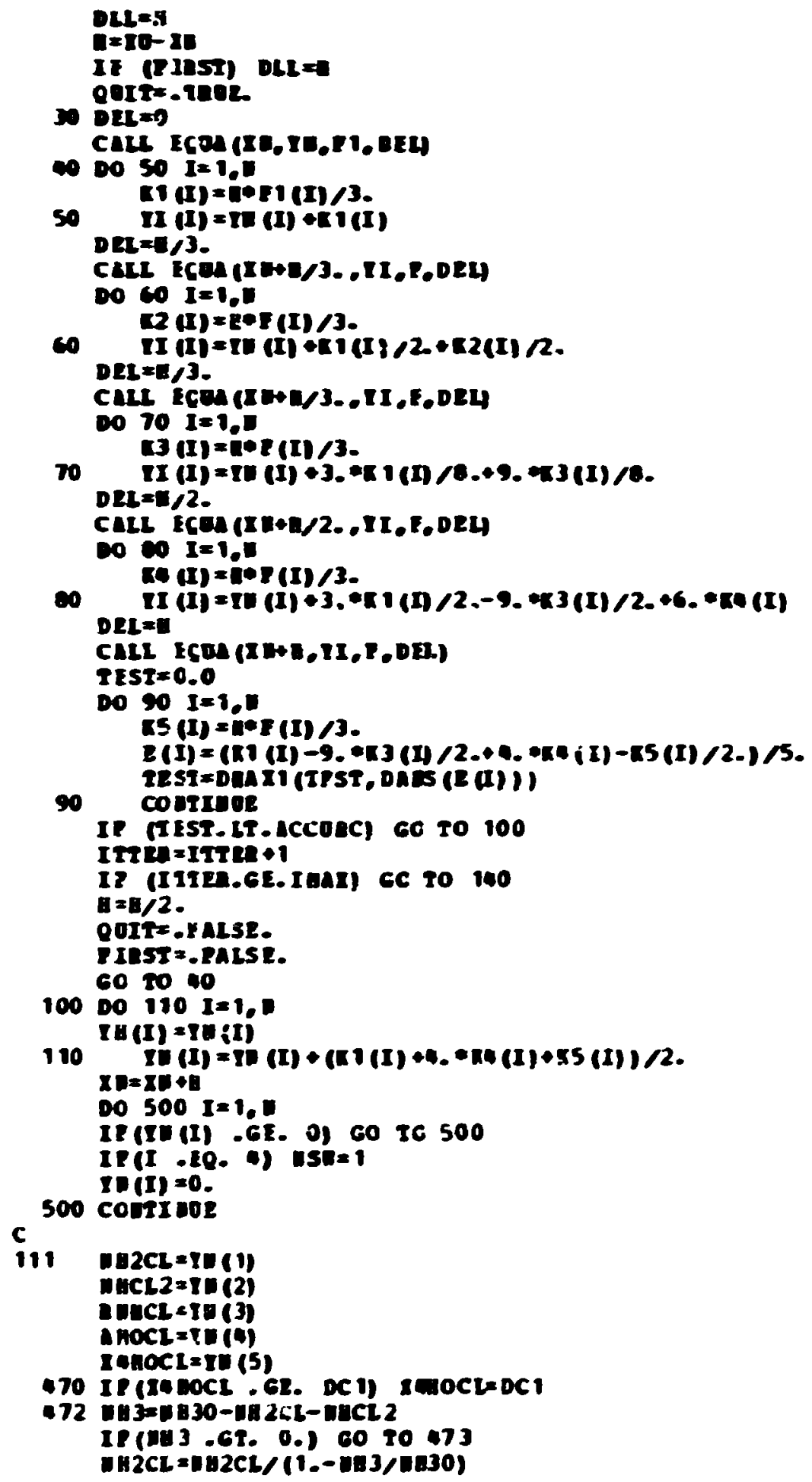




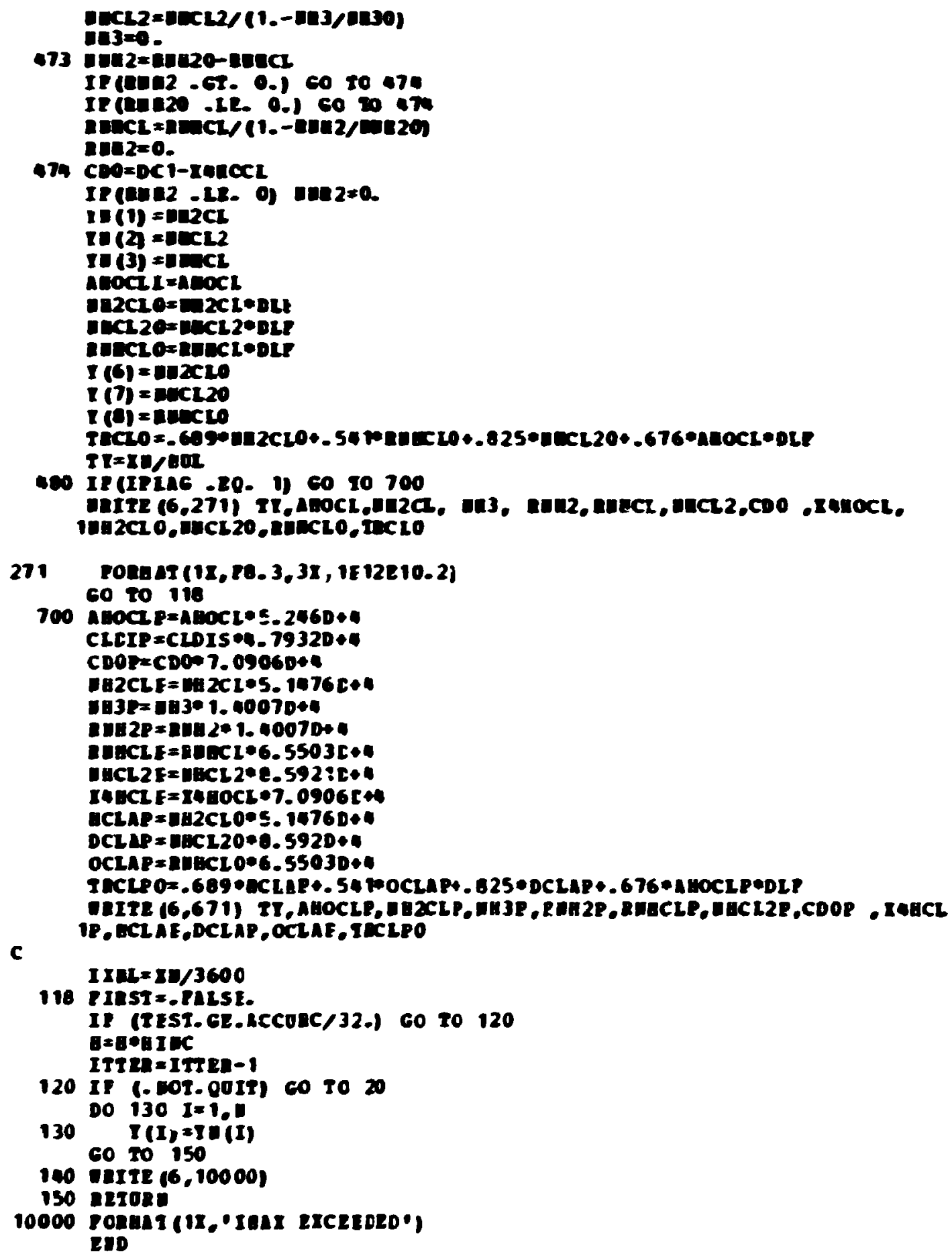




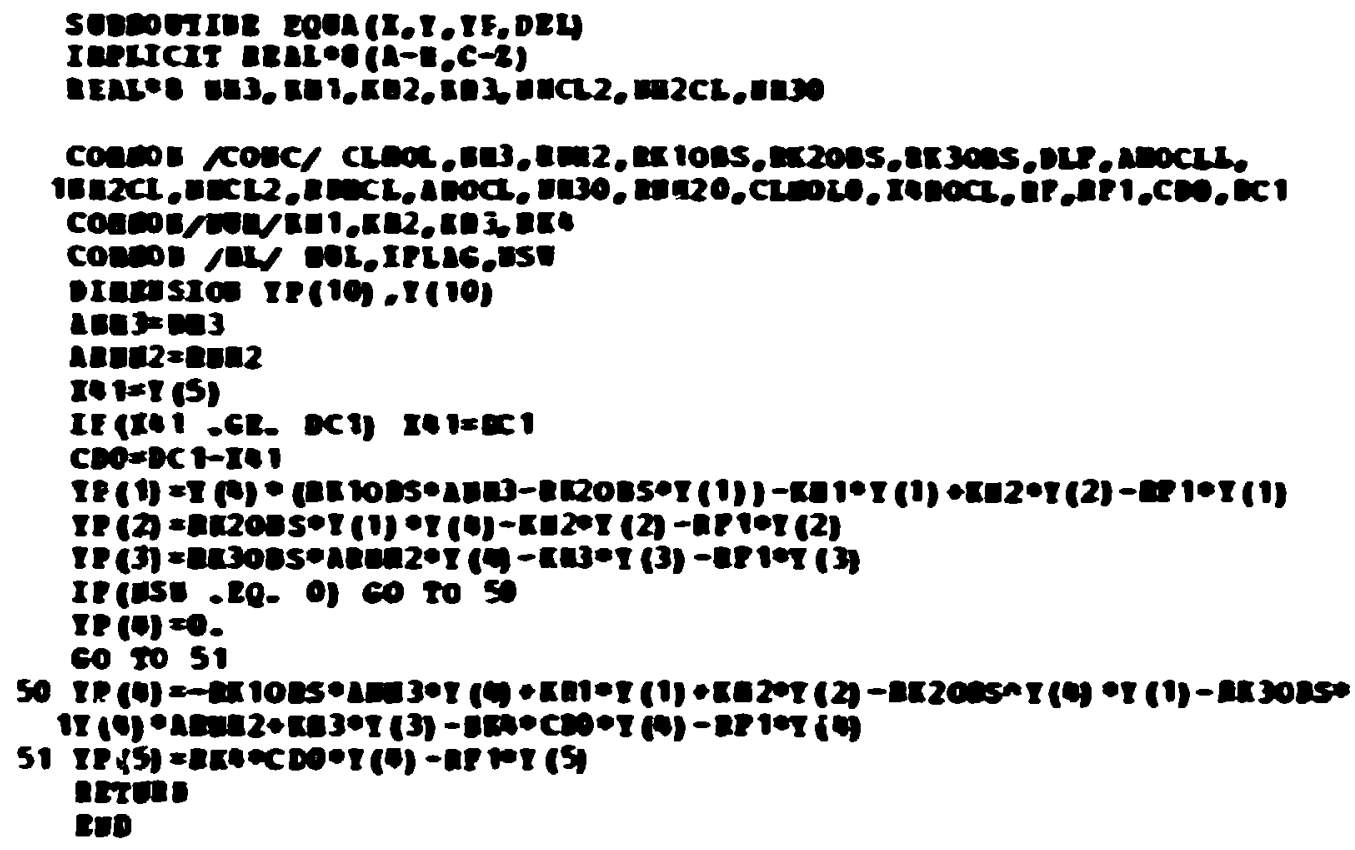

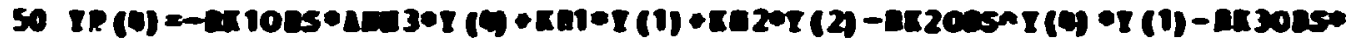

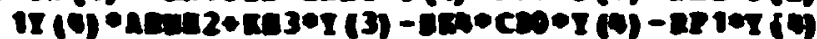

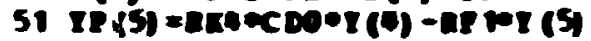

arene

200 
Appendix 2

Conpilation of Thernodyrazic and Kinetic Data for Reactions Involving $b$-Chlorination of a Number of Organic and Inorganic Compounds 
APPERIXIX 2

Thermodynanic and kinetic data on the following reactions are sumarized:

1. $\mathrm{Cl}_{2}+\mathrm{H}_{2} \mathrm{O} \rightleftharpoons \mathrm{HOCl}+\mathrm{H}^{+}+\mathrm{Cl}^{-}$

2. $\mathrm{HOCl} \rightleftharpoons \mathrm{H}^{+}+\mathrm{OCl}^{-}$

3. $\mathrm{HH}_{3}+\mathrm{H}_{2} \mathrm{O} \rightleftharpoons \mathrm{NH}_{4}^{+}+\mathrm{OH}^{-}$

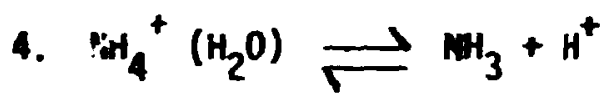

5. $\mathrm{HH}_{2} \mathrm{Cl}+\mathrm{H}_{2} \mathrm{O} \underset{\mathrm{FH}}{\longrightarrow}+\mathrm{HOCl}$

6. $\mathrm{CH}_{3} \mathrm{NH}_{2}+\mathrm{H}_{2} \mathrm{O} \rightleftharpoons \mathrm{CH}_{3} \mathrm{HH}_{3}^{+}+\mathrm{OH}^{-}$

7. $\left(\mathrm{CH}_{3}\right)_{2} \mathrm{NH}+\mathrm{H}_{2} \mathrm{O} \rightleftharpoons\left(\mathrm{CH}_{3}\right)_{2} \mathrm{HH}_{2}^{+}+\mathrm{OH}^{-}$

8. $\left(\mathrm{CH}_{3}\right)_{3} \mathrm{~N}+\mathrm{H}_{2} \mathrm{O} \rightleftharpoons\left(\mathrm{CH}_{3}\right) \mathrm{NH}^{+}+\mathrm{OH}^{-}$

9. $\mathrm{HH}_{3}+\mathrm{HOCl} \rightleftharpoons \mathrm{NH}_{2} \mathrm{Cl}+\mathrm{H}_{2} \mathrm{O}$

10. $\mathrm{NH}_{2} \mathrm{Cl}+\mathrm{HOCl} \rightleftharpoons \mathrm{NHCl}_{2}+\mathrm{H}_{2} \mathrm{O}$

11. $2 \mathrm{NH}_{2} \mathrm{Cl}+\mathrm{H}^{+} \rightleftharpoons \mathrm{NH}_{4}^{+}+\mathrm{NHCl}_{2}$

12. $2 \mathrm{NH}_{2} \mathrm{Cl} \longrightarrow \mathrm{NHCl}_{2}+\mathrm{NH}_{3}$

13. $\mathrm{CH}_{3} \mathrm{NH}_{2}+\mathrm{HOCl} \rightleftharpoons \mathrm{CH}_{3} \mathrm{NHCl}+\mathrm{H}_{2} \mathrm{O}$

14. $\left(\mathrm{CH}_{3}\right)_{2} \mathrm{HH}+\mathrm{HOCl} \rightleftharpoons\left(\mathrm{CH}_{3}\right)_{2} \mathrm{MCl}+\mathrm{H}_{2} \mathrm{O}$

15. $\mathrm{CH}_{3} \mathrm{NHCl}+\mathrm{HOCl} \rightleftharpoons \mathrm{CH}_{3} \mathrm{NCl}_{2}+\mathrm{H}_{2} \mathrm{O}$ 
16. $2 \mathrm{CH}_{3} \mathrm{maCl} \rightleftharpoons \mathrm{CH}_{3} \mathrm{MCl}_{2}+\mathrm{CH}_{3} \mathrm{MH}_{2}$

17. $\mathrm{CH}_{3} \mathrm{CONHCH}_{3}+\mathrm{HOCl} \rightleftharpoons \mathrm{CH}_{3} \mathrm{COHClCH}_{3}+\mathrm{H}_{2} \mathrm{O}$

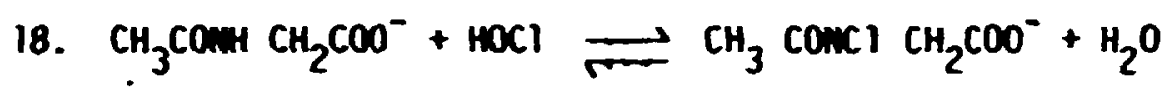

19. $\mathrm{HH}_{2} \mathrm{CONH}_{2}+\mathrm{HOCl} \rightleftharpoons \mathrm{NH}_{2} \mathrm{CONKCl}+\mathrm{H}_{2} \mathrm{O}$

20. $\mathrm{H}_{2} \mathrm{O} \rightleftharpoons \mathrm{H}^{+}+\mathrm{OH}^{-}$

21. Rate constants for M-chlorination of a numer of additional compounds relative to amonia. 
1. $\mathrm{Ci}_{2}+\mathrm{H}_{2} \mathrm{O} \rightleftharpoons \mathrm{HOCl}+\mathrm{H}^{+}+\mathrm{Cl}^{-}$

$$
\begin{aligned}
& K_{1}=\frac{\left[\mathrm{Cl}^{-}\right]\left[\mathrm{H}^{+}\right][\mathrm{HOCl}]}{\left[\mathrm{Cl}_{2}\right]} \\
& \begin{array}{ll}
t^{\circ} \mathrm{c} & k_{1} \times 10^{4} \\
& 1.46 \\
15 & 2.81 \\
25 & 3.94 \\
35 & 5.10 \\
45 & 8.05
\end{array}
\end{aligned}
$$

ref: R. E. Connick \&uan - tsan Chia, J, An. Chem, Soc, 81 1280 (1959)

rate constants

$k_{1}=5.60 \mathrm{sec}^{-1} \geq 0.45$ if the reaction is monomolecular

$k_{1}=0.1 \mathrm{l} / \mathrm{mole}-\mathrm{sec}$ if the reaction is bimolecular

(this has not been resolved)

ref: A. Lifshitz and B. Perlmutter - Hayman, J. phys. chem, 64, 1663 (1960).

2. $\mathrm{HOCl} \rightleftharpoons \mathrm{H}^{+}+\mathrm{OCl}^{-}$

$$
k_{2}=\frac{\left[\mathrm{H}^{+}\right]\left[\mathrm{UCl}^{-}\right]}{[\mathrm{HOCl}]}
$$


2. (concl.)

\begin{tabular}{cc}
$t^{\circ} \mathrm{c}$ & $k_{2} \times 10^{8}$ \\
\hline 0 & 2.0 \\
5 & 2.3 \\
10 & 2.6 \\
15 & 3.0 \\
20 & 3.3 \\
25 & 3.7
\end{tabular}

ref: G. M. Fair, J. C. Morris, S. L. Chang, I, Meil, ?, P, Burden, J. An. Water Works Assoc. 40. 1051 (1948).

3. $\mathrm{NH}_{3}+\mathrm{H}_{2} \mathrm{O} \rightleftharpoons \mathrm{NH}_{4}^{+}+\mathrm{OH}^{-}$

$$
K_{3}=\frac{\left[\mathrm{NH}_{4}^{+}\right]\left[\mathrm{OH}^{-}\right]}{\left[\mathrm{NH}_{3}\right]}
$$

$\begin{array}{cccc}t i c & k_{3} \times 10^{5} & t c & \frac{k_{3} \times 10^{5}}{0} \\ & 1.51 & 25 & 1.81 \\ 10 & 1.62 & 40 & 2.00 \\ 15 & 1.70 & 50 & 1.95\end{array}$

ref: H. Lunden, 1. chirr, phys, 5, 574 (1907) 
4. $\mathrm{HH}_{4}^{+}\left(\mathrm{H}_{2} \mathrm{O}\right) \underset{\mathrm{W}}{\mathrm{WH}}+\mathrm{H}^{+}$

$$
K_{4}=\frac{\left[\mathrm{Ni}_{3}\right]\left[\mathrm{H}^{+}\right]}{\left[\mathrm{NH}_{4}^{+}\right]}
$$

$\begin{array}{cccc}t^{5} c & k_{4} \times 10^{10} & t c & k_{4} \times 10^{10} \\ 0 & (0.83) & 30 & 8.06 \\ 5 & 1.25 & 35 & 11.3 \\ 10 & 1.86 & 40 & 15.7 \\ 15 & 2.73 & 45 & 21.4 \\ 20 & 3.98 & 50 & 28.9 \\ 25 & 5.68 & & \end{array}$

ref: R. G, Bates and G. D. Pinching, J. Res. Mat. Bur. Stand. 42,419 (1949)

5. $\mathrm{NH}_{2} \mathrm{Cl}+\mathrm{H}_{2} \mathrm{~N} \underset{\mathrm{C}}{\longrightarrow} \mathrm{HOC}:+\mathrm{NH}_{3}$

$$
\begin{aligned}
& K_{5}=\frac{[H O C 1]\left[\mathrm{NH}_{3}\right]}{\left[\mathrm{NH}_{2} \mathrm{Cl}\right]} \\
& K_{5}=9.0 \times 10^{-2} \exp (-14,000 / \mathrm{RT}) \text { moies } / 1 .
\end{aligned}
$$

rate constant: as a first order process (in the absence of competing $\mathrm{NH}_{3}$ ) the specific rate is givin by

$$
k_{5}=8.7 \times 10^{7} \exp (-17.000 / R T) \sec ^{-1}
$$

ref: M. L. Granstram, PhD Thesis, Harvard University, Nov. 1954, 
6. $\mathrm{CH}_{3} \mathrm{MH}_{2}+\mathrm{H}_{2} \mathrm{O} \rightleftharpoons \mathrm{CH}_{3} \mathrm{MH}_{3}^{+}+\mathrm{OH}^{-}$

$$
K_{6}=\frac{\left[\mathrm{CH}_{3} \mathrm{NH}_{3}^{+}\right]\left[\mathrm{OH}^{-}\right]}{\left[\mathrm{CH}_{3} \mathrm{NH}_{2}\right]}
$$

$\frac{t^{2} c}{0}$
10
20
30
40
50

$$
\begin{array}{r}
\frac{-\log x_{6}}{3.449} \\
3.405 \\
3.380 \\
3.367 \\
3.375
\end{array}
$$$$
\underline{k_{6} \times 10^{4}}
$$$$
3.56
$$$$
3.94
$$$$
4,17
$$$$
4,30
$$$$
4,22
$$$$
4.1 !
$$

ref: D. H. Everett and M. F. K. Kynne - Jones, Proc. Rcy. So (ZG Jonn), 177A, 499 (194i)

$$
\begin{aligned}
& \text { 7. }\left(\mathrm{CH}_{3}\right)_{2} \mathrm{NH}+\mathrm{H}_{2} \mathrm{O} \rightleftharpoons\left(\mathrm{CH}_{3}\right)_{2} \mathrm{MH}_{2}^{+}+\mathrm{OH}^{-} \\
& K_{7}=\frac{\left[\left(\mathrm{CH}_{3}\right)_{2} \mathrm{NH}_{2}^{+}\right]\left[\mathrm{OH}^{-}\right]}{\left[\left(\mathrm{CH}_{3}\right)_{2} \mathrm{NH}\right]}
\end{aligned}
$$

\begin{tabular}{cc}
$t^{\circ} \mathrm{c}$ & $-\log k_{7}$ \\
\hline 0 & -3.392 \\
10 & 3.307 \\
20 & 3.245 \\
30 & 3.203 \\
40 & 3.183 \\
50 & 3.175
\end{tabular}

$$
\begin{gathered}
k_{7} \times 10^{4} \\
\hline 4.055 \\
4.93 ? \\
5.689 \\
6.266 \\
6.56^{?} \\
6.68 ?
\end{gathered}
$$


7. (concl.)

ref: D. H. Fverett and W. F, K. Wyrne - Jones, loc : cit.

8. $\left(\mathrm{CH}_{3}\right)_{3} \mathrm{~N}+\mathrm{H}_{2} \mathrm{O} \rightleftharpoons\left(\mathrm{CH}_{3}\right)_{3} \mathrm{NH}^{+}+\mathrm{OH}^{-}$

$$
K_{8}=\frac{\left[\left(\mathrm{CH}_{3}\right)_{3} \mathrm{NH}^{+}\right]\left[\mathrm{OH}^{-}\right]}{\left[\left(\mathrm{CH}_{3}\right)_{3} \mathrm{~N}\right]}
$$

\begin{tabular}{ccc}
$\mathrm{t}^{\circ} \mathrm{c}$ & $-109 \mathrm{~K}_{8}$ & $\mathrm{~K}_{8} \times 10^{5}$ \\
\hline 0 & 4.591 & 2.564 \\
10 & 4.407 & 3.917 \\
20 & 4.261 & 5.483 \\
30 & 4.141 & 7.228 \\
40 & 4.059 & 7.297 \\
50 & 3.992 & 10.19
\end{tabular}

ref: D. H. Everett and W, F, K. Wynne - Jones, loc, cit,

9. $\mathrm{NH}_{3}+\mathrm{HOCl} \rightleftharpoons \mathrm{NH}_{2} \mathrm{Cl}+\mathrm{H}_{2} \mathrm{O}$

$$
\begin{aligned}
& K_{9}=\frac{\left[\mathrm{NH}_{2} \mathrm{Cl}\right]}{\left[\mathrm{NH}_{3}\right][\mathrm{HOCl}]} \\
& K_{9}=3.6 \times 10^{9} \text { at } 25^{\circ} \mathrm{C}
\end{aligned}
$$

ref: J, E. Draley, ANL/ES - 12 (1972) 
9. (conci.)

rate constant: 0 ver the temperature range $5-35^{\circ} \mathrm{C}$ the activation energy for the reaction is $3 \mathrm{kcal}$.

The theoretical rate constant is given by

$$
k_{9}=9.7 \times 10^{8} \exp (-3000 / R T) 1 / \mathrm{mole}-\mathrm{sec} .
$$

ref: J. C. Morris in Principles and Applications of Hater Chemistry, S. D. Faust and J. V. Hunter (ed,), John Wiley and Sons, Inc., N,Y. (1967), p. 27

$$
k_{g} \text { (obs.) }=\frac{k_{g} \text { (theoretical) is related to } k_{g} \text { (obs.) by }}{1+\frac{k_{a} K_{b}}{K_{w}}+\frac{K_{a}}{\left[H^{+}\right]}+\frac{K_{b}}{K_{w}}\left[H^{+}\right]}
$$

where $k_{a}=k_{2} ; k_{b}=k_{3} ;$ and $k_{w}$ is given by $k_{20}$

ref: I. Weil \& J, C. Morris, J. Am, Chem, Soc, 1․ 1664 (1949)

10. $\mathrm{NH}_{2} \mathrm{Cl}+\mathrm{HOCl} \rightleftharpoons \mathrm{NHCl}_{2}+\mathrm{H}_{2} \mathrm{O}$

$$
K_{10}=\frac{\left[\mathrm{NHCl}_{2}\right]}{\left[\mathrm{NH}_{2} \mathrm{Cl}\right][\mathrm{HOCl}]}
$$


10. (concl.)

$$
\mathrm{K}_{10}=1.35 \times 10^{6} \text { at } 25^{\circ} \mathrm{C}
$$

ref: Draley, loc, cit.

rate constant: the activation energy for this reaction is $7.3 \mathrm{kcal}$.

The theoretical rate constant is given by

$$
k_{10}=7.6 \times 10^{7} \exp (-7300 / R T) 1 / \text { mole }-\mathrm{sec},
$$

In mildly acid solutions

$$
k_{10}^{*}=k_{10} \quad k_{a} /\left[\mathrm{H}^{+}\right]
$$

where $k_{a}=k_{4}$

ref: J. C. Morris (1967) loc. cit., p. 28.

11. $2 \mathrm{NH}_{2} \mathrm{Cl}+\mathrm{H}^{+} \rightleftharpoons \mathrm{NH}_{4}^{+}+\mathrm{NHCl}_{2}$

$$
\begin{aligned}
& \mathrm{K}_{11}=\frac{\left[\mathrm{NH}_{4}^{+}\right]\left[\mathrm{NHCl}_{2}\right]}{\left[\mathrm{H}^{+}\right]\left[\mathrm{NH}_{2} \mathrm{Cl}\right]^{2}} \\
& \mathrm{~K}_{11}=6.7 \times 10^{5} \text { at } 25^{\circ}
\end{aligned}
$$


12. $2 \mathrm{NH}_{2} \mathrm{Cl} \longrightarrow \mathrm{NHCl}_{2}+\mathrm{NH}_{3}$

The activation energy for this reaction in the temperature range $7.49^{\circ} \mathrm{C}$ is $4.3 \mathrm{kca}$.

rate constant:

$$
k_{12}=80 \exp (-4300 / R T) 1 / \text { mole }- \text { sec. }
$$

ref: M. L. Granstrom, loc. cit.

13. $\mathrm{CH}_{3} \mathrm{NH}_{2}+\mathrm{HOCl} \rightleftharpoons \mathrm{CH}_{3} \mathrm{NHCl}+\mathrm{H}_{2} \mathrm{O}$

rate constant: over the temperature range $5-25^{\circ} \mathrm{C}$ the activation energy for the reaction is $1.9 \mathrm{kcal}$,

The theoretical rate constant is given by

$$
k_{13}=7.8 \times 10^{9} \exp (-1900 / R T) 1 / \text { mole }-\mathrm{sec} \text {. }
$$

ref: J. C. Morris (1967), loc, cit,, P. 32 ,

$$
\begin{aligned}
& k_{13} \text { (theoretical) is related to } k_{13} \text { (obs.) by } \\
& k_{13} \text { (obs.) }=\frac{k_{13} \text { (theoret) }}{1+\frac{k_{a} K_{b}}{k_{w}}+\frac{k_{a}}{\left[H^{+}\right]}+\frac{k_{b}}{k_{w}}\left[H^{+}\right]}
\end{aligned}
$$


40

13. (conc.)

where $k_{a}=k_{2} ; k_{b}=k_{b} ;$ and $k_{w}=k_{20}$

ref: 1. Weill and 1. C. Morris, Hoc, cit.

14. $\left(\mathrm{CH}_{3}\right)_{2} \mathrm{NH}+\mathrm{HOCl} \rightleftharpoons\left(\mathrm{CH}_{3}\right)_{2} \mathrm{NCl}+\mathrm{H}_{2} \mathrm{O}$

rate constant: over the temperature range $5-38^{\circ} \mathrm{C}$ (no change with temperature) the theoretical rate constant is given by

$$
k_{14}=3.3 \times 10^{8} \quad 1 / \text { mole }-\mathrm{sec} .
$$

ref: J. C, Morris (1967), loco. cit,, p, 34

$$
k_{14} \text { (theoretical) is related to } k_{14} \text { (obs) by }
$$

$$
k_{14}(\text { obs })=\frac{k_{14} \text { (theoret) }}{1+\frac{K_{a} K_{b}}{K_{w}}+\frac{K_{a}}{\left[H^{+}\right]}=\frac{K_{b}}{K_{w}}\left[H^{+}\right]}
$$

where $k_{a}=k_{2} ; k_{b}=k_{7} ;$ and $k_{w}=k_{20}$

ref: I. Weill and J. C. Morris, loco, cit, 
15. $\mathrm{CH}_{3} \mathrm{NHCl}+\mathrm{HOCl} \rightleftharpoons \mathrm{CH}_{3} \mathrm{NCl}_{2}+\mathrm{H}_{2} \mathrm{O}$

rate constent: $k_{15}=1.1 \times 10^{3} 1 / \mathrm{mole}-\sec$ at $25^{\circ} \mathrm{C}$.

The temperature coefficient has not been determined.

ref: J. C. Morris (1967), loc. cit., p. 32.

16. $2 \mathrm{CH}_{3} \mathrm{NHCl} \rightleftharpoons \mathrm{CH}_{3} \mathrm{NCl}_{2}+\mathrm{CH}_{3} \mathrm{NH}_{2}$

rate constant: $k_{16}=4.7 \times 10^{-2} \quad 1 /$ mole $-\sec$ at $25^{\circ} \mathrm{C}$

The temperature coefficient has not been determined.

17. $\mathrm{CH}_{3} \mathrm{CONHCH}_{3}+\mathrm{HOCl} \rightleftharpoons \mathrm{CH}_{3} \mathrm{COHClCH}_{3}+\mathrm{H}_{2} \mathrm{O}$

reaction rate: At $25^{\circ}$ the rate constant is

$$
k_{17}=1.4 \times 10^{-3} \quad 1 / \mathrm{mole}-\mathrm{sec} .
$$

18. $\mathrm{CH}_{3} \mathrm{CONHCH}_{2} \mathrm{COO}^{-}+\mathrm{HOCl} \rightleftharpoons \mathrm{CH}_{3} \mathrm{CONClCH}_{2} \mathrm{COO}^{-}+\mathrm{H}_{2} \mathrm{O}$

reaction rate: At $25^{\circ}$ the rate constant is

$$
k_{18}=5 \times 10^{-2} \quad 1 \text {,mole }-\mathrm{sec} .
$$


19. $\mathrm{NH}_{2} \mathrm{CONH}_{2}+\mathrm{HOCl}=\mathrm{KH}_{2} \mathrm{CONHCl}+\mathrm{H}_{2} \mathrm{O}$

reaction rate: At $25^{\circ}$ the rate constant is

$$
k_{19}=7.5 \times 10^{-2} 1 / \text { mole }- \text { sec. }
$$

ref: $(16,17,18,19)$ : J. C. Morris (1967), loc. cit.

20. $\mathrm{H}_{2} \mathrm{O}=\mathrm{H}^{+}+\mathrm{OH}^{-}$

$$
K_{20}=K_{w}=\left[\mathrm{H}^{+}\right] \quad\left[\mathrm{OH}^{-}\right]
$$

The temperature dependence of $k_{w}$ (at saturation vapor pressure) is given by

$$
\log K_{w}=\frac{P_{1}}{T}+P_{2} \ln T+P_{3} T+\frac{P_{4}}{T^{2}}+P_{5},
$$

where

$$
\begin{array}{ll}
P_{1}=3.12863 \times 10^{4} & P_{4}=-2,17087 \times 10^{6} \\
P_{2}=94.9734 & P_{5}=-6.06522 \times 10^{2} \\
P_{3}=-0.097611 & T=T^{2} \mathrm{~K}
\end{array}
$$

ref: F. H. Sweeton, R. E. Mesmer, and C. F. Baes, Jr., J. Solution Chem, 3. $191(1974)$. 
21. Sumary of rate constants for $\mathbf{N}$ - chlorination of a number of nitrogenous compounds relative to $\mathrm{NH}_{3}, \mathrm{~F}_{0}$ is the ratio of the rate constant for the particular reaction relative to that for tine reaction with $\mathrm{NH}_{3}$

TABLE I RATE CONSTANTS FOR

N-CHLORINATION RELATIVE TO $\mathrm{NH}_{3}(a)$

\begin{tabular}{|c|c|c|c|}
\hline $\begin{array}{l}\text { Ni trogenous } \\
\text { Compound }\end{array}$ & $\mathrm{pK}_{\mathrm{o}}\left(25^{\circ} \mathrm{C}\right)$ & $F_{s}=k_{u} / k_{r}$ & $\log F_{0}$ \\
\hline Wethylamine & 3.376 & (b) & 1.78 \\
\hline Dimethylamine & 3.226 & (b) & 1.73 \\
\hline Diethylamine & $3.06 ?$ & 23 & 1.36 \\
\hline Morpholine & 5.30 & 9 & 0,95 \\
\hline Diethanolamine & 5.12 & 9.3 & 0.97 \\
\hline Ethylaminoacetate & 6.27 & 2.0 & 0.30 \\
\hline Gljcine & 4.221 & 22 & 1.34 \\
\hline Alanine & 4.133 & 19 & 1.28 \\
\hline Leucine & 4.256 & 14 & 1.15 \\
\hline -Alanine & 3.765 & 33 & 1.52 \\
\hline Serine & 4.795 & 6.7 & 0,83 \\
\hline Glycylglycylglycine & 6.09 & 2.3 & 0,36 \\
\hline Chloramide & ca 15 & $5.5 \times 10^{-5}$ & -4.26 \\
\hline N-chlorme thyl amine & ca 13.8 & $1.8 \times 10^{-4}$ & -3.74 \\
\hline
\end{tabular}

(a) Based on reaction between $\mathrm{HOCl}$ and basic form of $\mathrm{N}$ compound,

(b) Computed from individual rate constants.

ref: J. C. Morris (1967), 10c, cit, , p, 37. 